Anuario Latinoamericano Ciencias Políticas y Relaciones Internacionales vol. 11, 2021

pp. 43-61

\section{Necropsy on Brazilian Democracy}

\section{Necropsia de la democracia brasileña}

\author{
Guilherme Simões Reis* \\ FEDERAL UNIVERSITY OF THE STATE OF RIO DE JANEIRO \\ BRAZIL \\ $\triangle$ guilherme.s.reis@unirio.br \\ https://orcid.org/0000-0001-7031-7167
}

\begin{abstract}
This article explains by what means ongoing democratic backsliding takes place in Brazil, after the pinnacle of its democratic experience. Unlike mainstream concerns about the death of democracies and the quality of democracy, it started neither by the action of outsiders nor through Executive aggrandizement. Institutions regarded as protectors against abuse of power, such as media, the judiciary, public prosecution, and parliament, led to the disruption of democracy. Consequences were militarization, party system deterioration and undemocratic elections, favoring farright extremist Bolsonaro.
\end{abstract}

KEYWORDS: democracy, coup, lawfare, military, elections, Brazil.

\section{RESUMEN}

Este artículo explica como ocurre el retroceso democrático en curso en Brasil, tras el apogeo de su experiencia democrática. A diferencia de las preocupaciones tradicionales acerca de la muerte de las democracias o de su calidad, este retroceso no empezó ni por la acción desde fuera ni a través del engrandecimiento del Ejecutivo. Instituciones consideradas protectoras contra el autoritarismo, como los medios de comunicación, el poder judicial, la fiscalía pública y el parlamento, llevaron a la ruptura de la democracia. Las consecuencias fueron la militarización, el deterioro del sistema de partidos y las elecciones no democráticas, que favorecieron a Bolsonaro.

PALABRAS CLAVE: democracia, golpe, guerra jurídica, militares, elecciones, Brasil.

* Professor at the School of Political Science at UNIRIO, PhD in Political Science from IESP-UERJ, coordinator of CAIPORA.
DOI:10.17951/al.2021.11.43-61 


\section{Introduction}

Despite not being free of problems, the end of military rule in 1985 led to the most stable and deeply democratic age in Brazilian history. Indeed, Brazilian hegemonic Political Science used to believe that democratic resiliency in the country was safe, as the institutionalization of the party system, free elections and Executive-Legislative relations seemed to be far advanced (Figueiredo \& Limongi, 1999; Palermo, 2000; Limongi, 2006).

However, the Brazilian case is an example of how democratic backsliding may be much faster than the progressive advancement of democracy. We may consider that Brazil's democratization process reached a pinnacle with the acceptance of electoral defeat by Fernando Henrique Cardoso's Party of Brazilian Social Democracy (PSDB) in 2002 and the alternation of power, followed by 13 years in which left-wing Workers' Party (PT) governed, winning four fully democratic elections in a row, with presidents Lula da Silva and Dilma Rousseff being elected. The dramatic end of that age leads to a fast democratic backsliding, as will be explained in this text.

Brazilian polity is also a useful example to discuss how some usual assumptions in political science may be misleading, as I will do in this article. The death of democracy happened in a way that diverges from mainstream diagnostics according to Levitsky's or Runciman's models (Levitsky \& Ziblatt, 2018; Runciman, 2018). Indeed, some upcoming reasons were already indicated in a previous text of mine with a similar title: "How democracy dies" (Reis, 2015). By ignoring some core elements, it is not possible to understand Jair Bolsonaro's phenomenon: he is not a cause of democratic breakdown, but rather its consequence and enhancement. Also, as I will discuss later, those authors emphasize a pernicious role of outsiders and support barriers as a solution. However, those very barriers may be undemocratic; they are supporting a specific market-oriented policy and not properly democracy. According to Webster's Dictionary, autopsy (or necropsy) may be defined as "a post-mortem examination to determine the cause of death". Of course, you may identify precisely the defunct. Authors are discussing the death of democracy but looking to a wrong corpse. I will address this problem in "The downfall" section.

The improvements and disruption of Brazilian democracy may be graphically noticed as measured by V-Dem indices for different conceptions of democracy (Coppedge et al., 2017): Electoral, Deliberative, Liberal, Participatory, and Egalitarian (Figure 1). There was a sharp improvement in re-democratization in 1985 and the new Constitution in 1988, a slighter one in the election of Lula in 2002, and a dramatic slump since the 2015 economic crisis and 2016 coup.

This text aims to make a necropsy on Brazilian democracy, exploring how it died. It will be organized this way: in the following section, I will make a brief overview of Brazilian undemocratic history and explain why those 13 years should be considered the most democratic ever. After that, the analysis will 


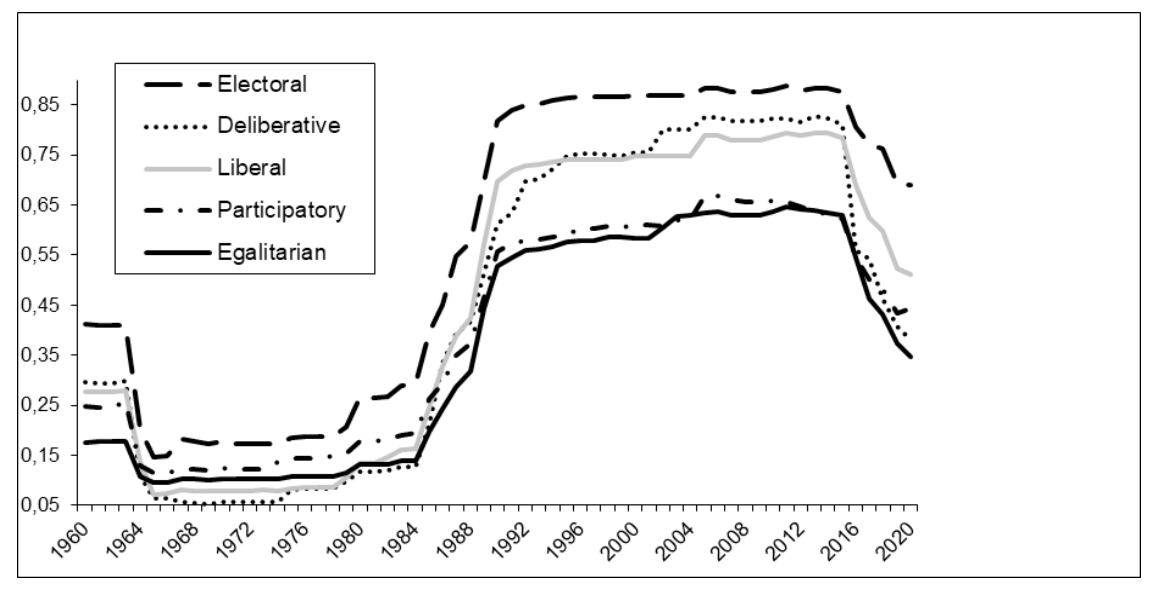

Source: V-Dem (Electoral Democracy Index; Deliberative Democracy Index; Liberal Democracy Index; Participatory Democracy Index; Egalitarian Democracy Index).

move to the de-democratization process that began when Rousseff was ousted from the presidency, divided into three more sections besides the conclusion.

\section{Undemocratic chain}

Brazilian history is mostly not a democratic one. Independence from Portugal in 1822 was followed by the introduction of an Empire in which the king had substantial powers, always having the last word due to what was euphemistically called the Moderator Power, not being analogous to current parliamentary monarchies. The proclamation of the republic in 1889 was a military coup, with the introduction of the so-called Sword Republic not leading to more civil liberties than the previous regime. Five years later, it was succeeded by the Old Republic, in which election frauds were the rule, and most of the time rural oligarchies from the states of São Paulo and Minas Gerais took turns holding the presidency. Besides that, merely $5 \%$ of people voted for president in that First Republic. That undemocratic electoral regime ceased with the Getúlio Vargas coup, known as the Revolution of 1930, which led to the forging of many important institutions, state-owned companies, and social welfare in Brazil. In 1937, that dictatorship centralized its power even more, starting the so-called New State.

Brazil would know a polyarchic regime (Dahl, 1971) only after the end of the New State, in 1945. However, the very first election was disputed by military candidates and, only three years afterward, the recently legalized and electorally strong Communist Party was made illegal again. Elections were not characterized by easy acceptance of the ballot results, and among the most
Necropsy on Brazilian Democracy

Guilherme Simões Reis

Figure 1.

Indices for different conceptions of democracy 
Dossier América Latina: Brasil turbulent events, we may highlight the failed assassination attempt of uncompromising opposition leader Carlos Lacerda in August 1954 and the Vargas suicide in the very same month, not to mention coup attempts (Santos, 2017).

The left-wing Brazilian Labour Party was growing from election to election (Soares, 2001) and indeed had a vice president, João Goulart, who became president after conservative Jânio Quadros resigned from office. However, the Armed Forces only accepted Goulart's presidency after a change in the system of government, from presidential to parliamentary since presidents in the latter usually have much less power than in the former. Goulart accepted those terms, but the regime returned to presidentialism after the people's decision in a referendum in 1963. Once more, most of the Armed Forces did not tolerate this and a coup d'état in 1964 ousted the president and led to 21 years of violent military dictatorship.

Although considered by Alvarez et al. (1996) as democratic, the first presidential election in 1985 was indirect, just like the ones held under dictatorship. Additionally, as the winner Tancredo Neves died before the beginning of his term, Vice President José Sarney took office. I must also mention that illiterate people were not allowed to vote throughout Brazilian republican history until the enactment of the 1988 Federal Constitution. The very first free election, in 1989, with biased participation of the press (Goulart, 2008), was followed in 1992 by the impeachment of Fernando Collor, accused of corruption.

In any event, stability endured ever since. Fernando Henrique Cardoso, elected in 1994, had a majority coalition and could make neo-liberal state reforms with strong parliamentary support (Palermo, 2000). On the one hand, the government coalition schemed to change the rules to allow Cardoso to be re-elected in 1998 (Rodrigues, 2014). On the other hand, he did accept his party's candidate's electoral defeat in 2002 and Brazil saw a democratic alternation of power, with left-wing Lula da Silva as the new president.

During their three and a half presidential terms, PT's governments strengthened predictable enforcement. The autonomy of the Federal Police and Public Prosecutor's Office has been considerably increased compared to previous governments, which closely controlled investigations themselves. However, the public's perception of corruption increased, due to the media and the Judiciary "criminalization of politics" (Santos, 2017; Marona \& Barbosa, 2018; Feres Júnior \& Sassara, 2018; Veiga et al., 2019), reaching its worst level one year before the 2016 coup, according to Transparency International's Global Corruption Barometer, and worsening again in 2017 as inducted president Michel Temer reversed policies against corruption (see Figure 2).

Other measures taken by the PT strengthened checks on the Executive. For the head of the General Prosecutor's Office of the Republic (and also the heads of the federal universities), the president of the Republic could choose any candidate from a "triple list" (a list comprised of three names, the first of which received the most votes from her or his colleagues); although, different from previous officeholders, Lula and Rousseff always chose the first name on 


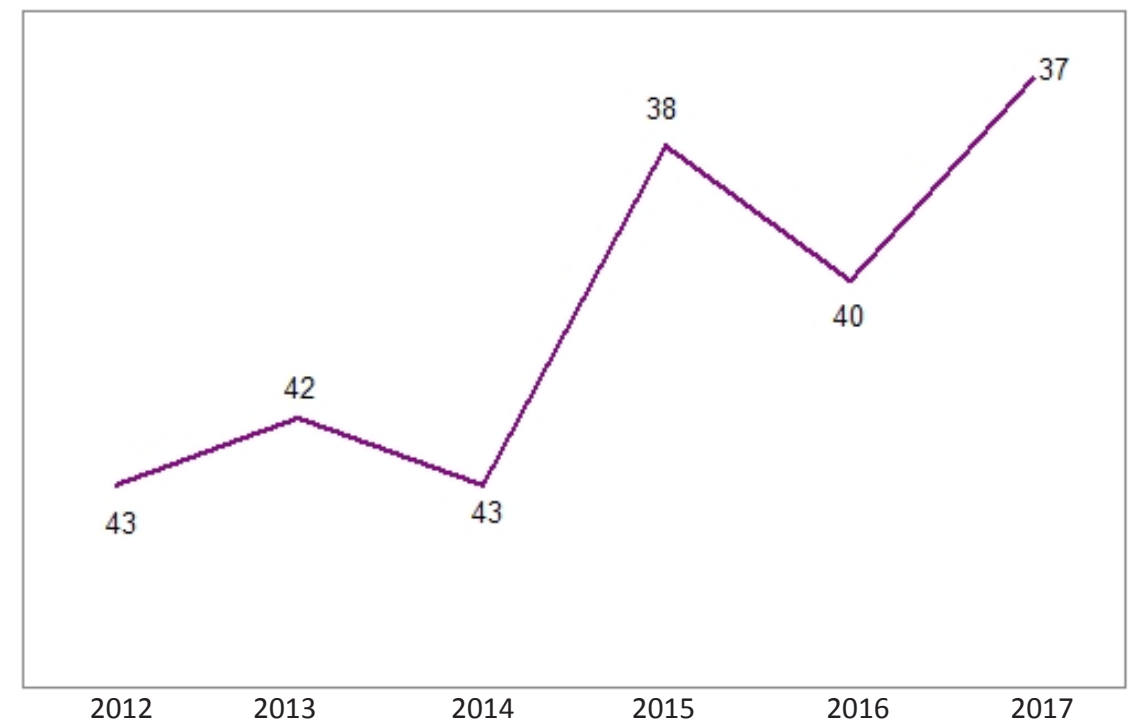

Necropsy on Brazilian Democracy

Guilherme Simões Reis

Figure 2.

Corruption Perceptions Index 2017

Source: Transparency International / Global Corruption Barometer.

the list, the most voted one. In addition to this, Rousseff enacted a law that stated that only policemen at the top of their career with the Federal Police could be chosen as the Director-General of that bureau. Lula and Rousseff could also indicate most of the justices of the Supreme Court but made no partisan choice.

Additionally, Lula created or re-created national conferences and councils to spread the people's participation in public policies, such as those for the Promotion of Racial Equality, for Women's Rights, for Fighting Discrimination, for Disabled People's Rights, for Elderly People's Rights, for the Youth, and Cities, as well as the National Commission of Indigenous Policy (Pogrebinschi, 2010).

\section{The downfall}

Great waves of massive, heterogeneous popular protests in 2013 (Bringel, 2013; Reis \& Soares, 2017) began a change in the mood of Brazilian politics, with less acceptance of the rules of the game, great dissatisfaction with political parties, and less control by traditional organized social movements. This article will focus, hereafter, on the eight-year period until the beginning of 2021, in a declining democratic trend.

The media narrative that PT's corruption broke the Brazilian economy (Azevedo, 2017, for example) boosted the anti-PT and anti-politics feelings and desire for a political change, be it democratic or not, and without a clear 
Dossier América Latina: Brasil

Figure 3. GDP Growth in Brazil direction, favoring someone not identified with political class (Reis \& Soares, 2017). The bad economic moment also impacted people's perceptions, and GDP growth in Brazil was almost null in 2014 and fell again in 2015, keeping the same negative outcome in 2016, as Figure 3 shows. The economic crisis was considerably caused by the way corruption investigations in Operation Car Wash were held by judge Sérgio Moro and Federal Police, affecting state oil company Petrobras, engineering and construction companies, and investments (Belluzzo, 2018).

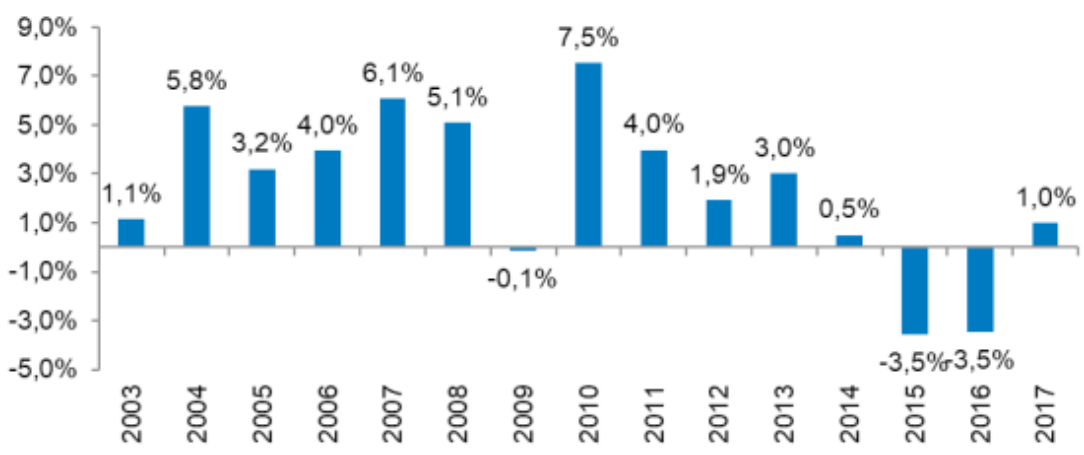

Source: Tinoco \& Giambiagi (2018, p. 9).

Cardoso's party PSDB lost the runoff against the PT for the fourth time in 2014, but its candidate, Aécio Neves, did not accept the result, differently from the previous three defeats. The second term of Lula's successor, Dilma Rousseff, would suffer undemocratic pressures until its premature end (Santos, 2017).

Rousseff's impeachment process, distinctly from Collor's, had no relation to corruption. The accusation of manipulating the federal budget dealt with measures which happened in previous and subsequent national and local governments, being neither serious enough (Carvalho, 2018, pp. 105-115) nor enough of a felony to be considered what is known in Brazil as a "crime of responsibility", the type of crime necessary for an impeachment to take place. Only two days after the impeachment was concluded, the same maneuver of which Rousseff was accused was fully legalized in a bill. Indeed, majority opposition sought an excuse to oust an undesired president (Löwy, 2016; Semer, 2016; Reis, 2017). It means that elections in Brazil ought not to be considered democratic any longer, as they are not decisive (O'Donnell, 1999) and do not follow the rule of the ex-post irreversibility (Alvarez et al., 1996).

The impeachment was transformed into a vote of no confidence, like the one that exists under parliamentary systems, what is obviously illegal and ignores the popular sovereign decision in a previous direct election for a limited and fixed presidential term. Therefore, it has been called a "coupeachment" (Klein, 2016) or an institutional, constitutional, or parliamentary coup (Löwy, 
2016; Santos, 2017; Pereira da Silva, 2018). By stretching the rules, the opposition disrespected core elements of democracy, with the practical consequence of making any left-wing government unfeasible. This was made clear by the speech of the opposition leader in the lower house, PSDB Congressman Miguel Haddad, during the impeachment process:

Today, we are no longer judging only the nature of the many crimes committed by President Dilma Rousseff which are shown daily in the newspaper headlines. What we are deciding today with our vote in the Chamber of Deputies and afterwards in the Senate is the future of a country destroyed by a president of the Republic who, with arrogance, 1) humiliated the parliament; 2) ruled with her back to the people, who expected from her leadership better days and a better life but received deception and systematic lies; and whose loyalty is not to the nation nor to Brazilian people but to her narrowminded ideology.

Additionally, other than the intention of a policy switch (Stokes, 2001; Reis, 2016), a reason for the coup seems to be stopping corruption investigations (Fernandes, 2016), as a famous leaked telephone statement from Senator and future Minister of Planning Romero Jucá shows: "It is necessary to change the government to stop this 'bleeding' [... in a great national agreement] with the Supreme Court and everything else.. Traditional pro-coup parties such as PSDB and Temer's Party of the Brazilian Democratic Movement (PMDB) were also associated with corruption by voters, having a much worse electoral performance than the PT in 2018, as Figure 4 shows. The situation favored outsiders and back-benchers, such as far-right extremist Jair Bolsonaro (Reis \& Soares, 2017), whose Social Liberal Party (PSL), tiny before his candidacy, became the second largest one in the lower house. ${ }^{1}$

There is a wave of political science best-sellers concerned about the democracy crisis in the world and the advancement of extremism, often presenting it as the death of democracy. Although agreeing with this general trend, I shall caution about core problems in the definition of the concept of democracy. Consequently, its autopsy is recurrently misdirected: while some democratic elements are perceived as risks, there are undemocratic ones that are presented as a remedy or as minor mischiefs.

Przeworski's (2019) assumptions share Schumpeter's idea that "the democratic method never works at its best when nations are much divided on fundamental questions of social structure" (Schumpeter, 1942, p. 298). Indeed, Przeworski (2019, p. 20) considers that: "When political parties are highly ideological, when they believe that essential issues or values are at stake, they see their opponents as enemies who must be prevented from coming to office

1 By the end of 2019, Jair Bolsonaro withdrew from PSL, having no party ever since. Only one of his sons remained as a PSL member, congressman Eduardo Bolsonaro.
Necropsy on Brazilian Democracy

Guilherme Simões Reis 


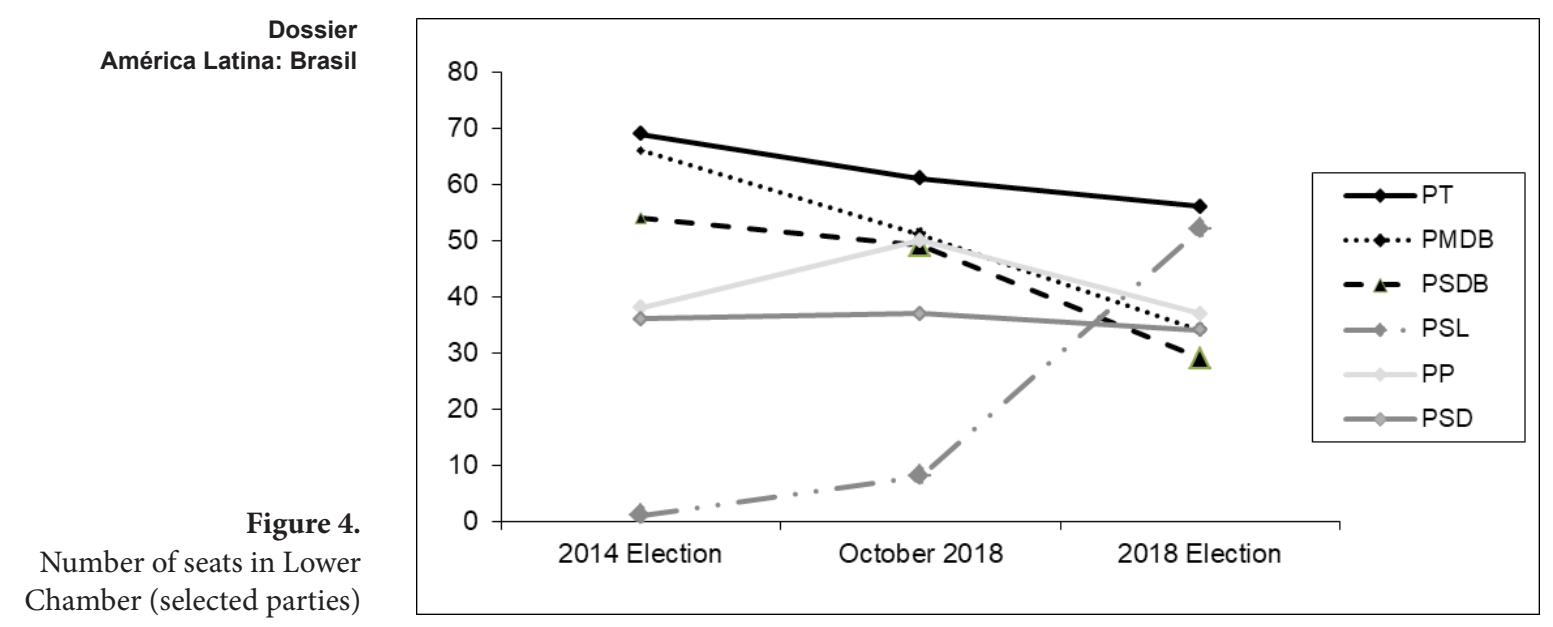

Source: Author (using data from G1, 08 October 2018).

by any means.". According to him (Przeworski, 2019, pp. 18-19), the stability of democracy depended on a specific agreement: working-class parties accepted capitalism, unions moderated their demands, and "bourgeois parties and organizations accepted some redistribution of income", with governments organizing that compromise. The difficulty for preserving that arrangement came from the loss of class roots and ideology by political parties, and from the fact that "unions lost much of their capacity to organize and discipline workers". Those very changes would have as an effect higher income inequality with a reduced slice of the pie for workers. It would make voters susceptible to "populist" speech on the left as well as on the right.

Mainstream political science often shares that perception and expects that responsible governance lies in moderating demands and accepting that status $q u o$, not "expecting too much from democracy". Just like what happens among most of the old established political parties while holding office in Western Europe. According to that approach, changes should be the least dramatic possible, taking place only when they are almost consensual, in the Burkean way (Burke, 1790). However, all outsiders, either anti-neoliberal left-wing or far-right extremists, are equally labeled as "populists". Any challenge to that political-economic consensus is viewed as radicalization and as a danger to democracy. Political science often follows the Schumpeterian idea that the value of democracy lies in stability and that no bond between popular preferences and implemented policies may be a serious concern.

Levitsky and Ziblatt (2018) consider as democratic, even quoting Madison, a polity ruled by an establishment that makes all efforts to avoid any volatility or renewal, by building entrance barriers. That establishment, grounded in pre-existent political parties, is compromised with both endogenous tolerance and free-market policy. According to these authors, outsiders, either 
anti-neoliberal left-wing or far-right extremists (they mention a wide variety of politicians from different times and places), were expected to increasingly use demagogic speech (which is, at once, anti-elite and authoritarian) and erode democracy from inside. Therefore, even hard means to take out those outsiders may be acceptable or at least understandable ${ }^{2}$ :

[...] demagogue's initial rise to power tends to polarize society, creating a climate of panic, hostility, and mutual distrust. The new leader's threatening words often have a boomerang effect. [...] the opposition may conclude that, for the good of the country, the government must be removed via extreme measures impeachment, mass protest, even a coup. (Levitsky \& Ziblatt, 2018, p. 76)

Legislatures may also overindulge their constitutional prerogatives. Take the 2012 impeachment of President Fernando Lugo in Paraguay. Lugo, a leftist ex-priest, was elected in 2008, ending the Colorado Party's sixty-one-year run in power. An outsider with few friends in congress, Lugo faced impeachment attempts throughout his presidency. [...] According to one observer, the trial was an "obvious farce... Lugo's impeachment barely even rose to the level of show trial." Strictly speaking, however, it was legal. (Levitsky \& Ziblatt, 2018, p. 110)

Runciman (2018) is also concerned about "right and left populists" and so does he see a crisis in a modern democracy. Attacks on representative government that are not led by militaries, but by businessmen and bankers, are viewed in a variety of ways throughout the book: as conspiratorial theories, as metaphors of coups, as disguised coups, or as distortions on democracy. Runciman emphasizes more the difficulty to undoubtedly identify a subtler coup than gives answers. In any event, he is also not very concerned about a connection between preferences and policies, in two main ways: 1) like Levitsky and Ziblatt (2018), he does not see economic elites biasing outcomes as a major problem, and 2) similarly to Przeworski (2019), he considers that democracy is going to end just because of increasing popular demands for solutions ("supercharged solutionism") and claims for personal recognition ("supercharged expressionism"), the very elements he pointed out as what makes democracy worth (respect and long-term benefits). According to him, they would be increasingly not possible together anymore.

2 Authors do say that those actions are "constitutional hardballs", which violate "norms of toleration and restraint", but the examples they use throughout the book show more indulgence towards establishment players than when it comes to outsiders. A good example is how they discuss George W. Bush's role. They imply that his USA Patriot Act was "authoritarian", or an "abuse of power" (p. 93) and they affirm that during his government there was a "decline in forbearance"; however, they also say that only since Trump's candidacy "the window was now also open to true outsiders" (p. 53). Levitsky and Ziblatt's (2018) many given examples of establishment players overturning democracy do not lead them not to relate intolerance to outsiders.
Necropsy on Brazilian Democracy

Guilherme Simões Reis 
Dossier América Latina: Brasil

Figure 5.

Media Integrity, Judicial Independence, and Effective

Parliament
The debates on democratic backsliding in world politics are often directed towards the issue of Executive aggrandizement. It is a historical concern in liberal and republican roots of political thought (Locke, Burke, Montesquieu, and Constant, for instance). The need for "horizontal accountability" (O’Donnell, 1998; Diamond \& Morlino, 2005) has been expressed mainly because of this. Therefore, some variables on which literature focuses the most are media integrity, judicial independence, and effective parliament.

According to International IDEA's Global State of Democracy Indices, all three had been quite stable in Brazil since the enactment of the new Constitution in 1988, until suffering a sharp decrease since the 2015 economic crisis (see Figure 5). However, the democratic breakdown in 2016 was caused by a cartel agreement between those very actors: the media, Judiciary and Parliament majority (Perissinotto, 2016; Reis, 2017; Santos, 2017; Chalhoub \& Lima, 2018; Engelmann, 2018; Feres Júnior \& Sassara, 2018; Marona \& Barbosa, 2018), backed by then-Vice President Michel Temer.

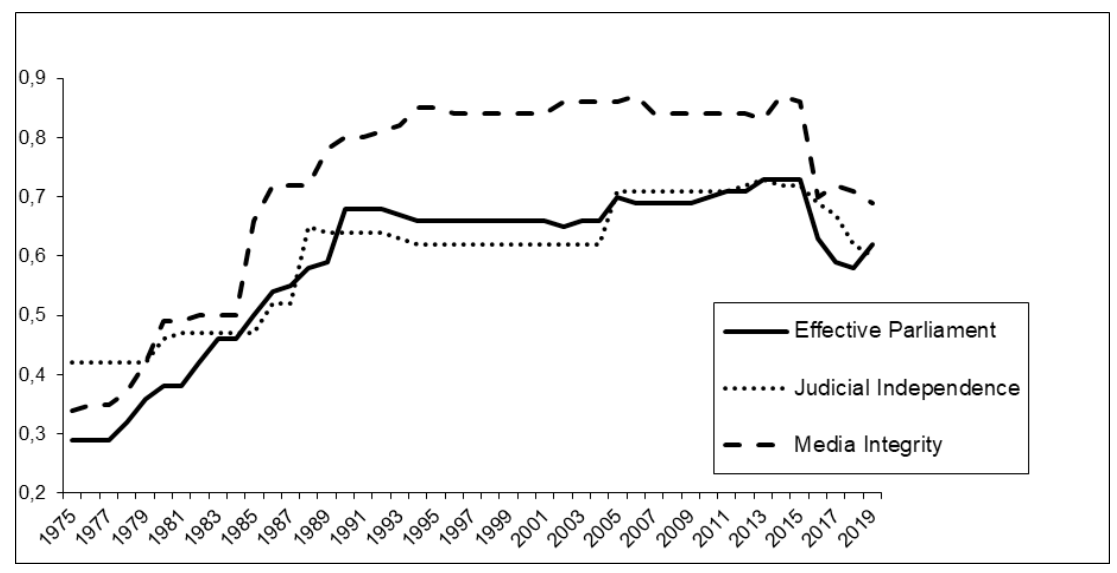

Source: GSoD Indices 2019.

There is a new and subtler kind of coup that is becoming more common in Latin America than old-style military ones (Coelho, 2016; Löwy, 2016; Santos, 2017; Pereira da Silva, 2018). Those who control the Judiciary and do not suffer opposition from the Armed Forces, whether in the Executive or not, may be able to oust the opposite side if there is no tolerance and the conflicts are not de facto regulated by institutionalized rules - like well- known distinctions between "antagonism" and "agonism", and between "adversaries" and "enemies", according to the concepts developed by Mouffe $(2000,2005)$. Protests both in favor of and against the coup happened, but violent police repression victimized those who tried to avoid a democratic breakdown. 
As a matter of fact, Rousseff had already enacted a criticized Anti-Terrorism Bill which could be used against activists, and indeed it became an obstacle to those who attempted to defend the president herself against the coup. Before "coupeachment" there was also a process of expansion of Military Justice responsibilities, with consequences such as lack of checks on law enforcement misconduct by officers, particularly with the increasing use of the National Public Security Force in major police operations (Lessing, 2018; Del Río \& Gomes, 2018; Del Río \& Rodrigues, 2018). This situation, however, would worsen with the new government, as will be explained in the following section.

\section{Militarization}

Quite unpopular, Temer assured his survival in office not only by bargaining with Parliament, the Judiciary, and businessmen but also through militarization of his regime. Temer recreated the Cabinet for Institutional Security, to be led by General Sérgio Etchegoyen, a fierce critic of the National Truth Commission and a relative of key repressive agents of the previous military dictatorship (Reis, 2016). Temer also chose a military officer for Minister of Defense, which had not happened in Brazil since the end of Cardoso's first term as president, in 1999 (Arias, 2018). However, the most radical decision by Temer towards militarization was perhaps the unprecedented authorization of federal military intervention in public security in the state of Rio de Janeiro. In practice, this put the head of that operation above the state governor himself with regards to law enforcement, being different from the aforementioned operations by the National Public Security Force (Lessing, 2018).

Before the presidential election, Presiding Supreme Court Judge Dias Toffoli invited General Fernando Azevedo e Silva, a member of the military close to Bolsonaro ${ }^{3}$, to be his personal advisor (Brigido \& Sassine, 2018). Toffoli also said that the putsch of 1964 should not be called a coup, but a "movement", adding that people "chose to blame the military" but the left was also responsible for that situation. Bolsonaro began his political career after retiring as a military officer and always defended not only conservative views but also narrow military interests, including refusing any criticism or punishment for the military dictatorship.

As a presidential candidate, Bolsonaro chose General Hamilton Mourão to be his vice president. A strong supporter of Bolsonaro's candidacy, General Augusto Heleno Pereira has been chosen to be one of his closest advisors, as the head of the Institutional Security Cabinet (Gabinete de Segurança Institucional, GSI). Additionally, Bolsonaro appointed members of the military

3 Eventually, Azevedo was appointed as minister of Defense by Bolsonaro. However, their relationship worsened due to disagreements concerning pandemic and, in March 2021, he was fired, in a decision with unpredictable consequences.
Necropsy on Brazilian Democracy

Guilherme Simões Reis 
Dossier América Latina: Brasil

for an unparalleled number of offices and the management of the largest slice of budgetary pie since the end of military dictatorship. That includes stateowned firms and many positions in the cabinet, including Civil House (chief of staff) and even Health during COVID-19 pandemic (Vianna, 2021).

In a public demonstration of authoritarian far-right agenda, GSI head General Heleno informed that the Brazilian Intelligence Agency was spying on Brazilian cardinals because of the meetings with Pope Francis about the Synod of Bishops for the Pan-Amazon region. According to him, those were "alarming" meetings towards a "progressive agenda" and opposition to the government which needed to be "neutralized". By "progressive agenda" he meant the discussion on climatic changes and the lives of indigenous peoples and quilombolas (traditional black communities that descend from former slaves). More recently, referring to an investigation on charges against Bolsonaro, Heleno said that "it is inconceivable and even unbelievable", and then threatened by stating that "it may lead to unpredictable consequences to national stability".

Not only an authoritarian and violent faction of the Armed Forces is important inside Bolsonaro's government, but also there are clues of connections with mafia-like paramilitary groups called "militias" (Paiva \& Do Sul, 2019; Calixto, 2019). ${ }^{4}$ Following Bolsonaro's path, there was also an increase in the number of military candidates and voting winners in the elections for many offices.

According to Cheibub (2006, p. 18), "the military, once activated into politics, are hard to control", and that is the reason why authoritarian legacies may lead to shorter-life democracies, particularly if they follow military dictatorships. Indeed, as General Eduardo Villas Bôas admitted, the Army High Command planned together a message published by him on Twitter inducing the Supreme Court to deny Lula's petition for writ of habeas corpus. Together with other stages of Lula's judicial process, it biased presidential elections, an issue I will address in the following section.

\section{Undemocratic election}

Far-right personalistic extremism represented by new president Bolsonaro has been boosted by the undemocratic disruptive behavior of institutions that are supposed to put checks on government. Therefore, more attention should be directed to the private media and the Judiciary, not to be taken for granted as neutral actors.

Favorite to win the 2018 presidential election, former president Lula has been condemned and lost his political rights in a politicized judicial process (Weisbrot, 2018; Marona \& Barbosa, 2018) in which his constitutional right to

\footnotetext{
4 In order to read more about how militias work, see Phillips (2018) and Manso (2020).
} 
due process was disrespected. Plea bargaining (delação premiada) "Snitching Rewards" were adopted in Brazil in a biased way, disrespecting due process and transferring the burden of proof to the accused (Avritzer, 2018). Sérgio Moro, the same judge who condemned Lula with no material evidence to prove the corruption charges against him in the Car Wash Operation in a lawfare case (National Coordination of the Homeless Workers Movement, 2018; Marona \& Barbosa, 2018), was rewarded by being chosen as the Minister of Justice and Public Security by then president-elect Bolsonaro. ${ }^{5}$

Public prosecutors involved in the Car Wash Operation and judge Moro schemed together in order to have support in the media and to impact elections, concerned about not allowing PT's success. It became clear when some private chats between them in the Telegram application were leaked (Duarte, 2020; Estrada, 2021). Brazilian Public Prosecution, following Thatcher and Sweet's (2003) discussion on delegation, is a non-majoritarian institution, that is, it is not accountable to people's democratic vote. Considering the authors' model, it is a non-majoritarian institution with a broad and eventually enlarged ex-ante agency and exposed to very little ex-post control, enjoying a substantial "zone of discretion". Therefore, we ought to acknowledge that its misuse of power is no less harmful to democracy than the issue of Executive aggrandizement.

Lula led all the polls, and his interdiction predictably changed the election result (see Figure 6). Although the PT's alternative for the presidential race, Fernando Haddad, grew in the polls and reached the runoff, he was far from Lula as a favorite against Bolsonaro, who was already in the lead in the polls when Lula's candidacy was not considered as an option. Then, a biased judicial process determined the result of the 2018 Brazilian presidential election (Londoño \& Casado, 2019), which must not be considered fair.

However, other serious problems also happened in this electoral process. Bolsonaro, in both his 28-year career as Congressman and in his presidential campaign, manifested intolerance against the left, support for the violation of human rights and the military dictatorship, and offended minorities and vulnerable groups, such as women, blacks, indigenous peoples, and homosexuals (Forrest, 2018). While running for president, he stated that PT politicians and supporters should be shot by a firing squad and that they would be sent to Ponta da Praia, an execution site during the military dictatorship. Unsurprisingly, widespread violence accompanied his campaign, at levels unparalleled with previous national elections. Bolsonaro himself has been stabbed, in not yet fully known circumstances.

Besides his hate speech, some illegal elements may have helped in Bolsonaro's triumph. The extremist contender's businessmen supporters allegedly paid for sending voters massive fake news against PT candidate Fernan-

5 It was such a powerful new Ministry, controlling most of the law enforcement institutions, that it has been called a "Super-Ministry" by the press.
Necropsy on Brazilian Democracy

Guilherme Simões Reis 


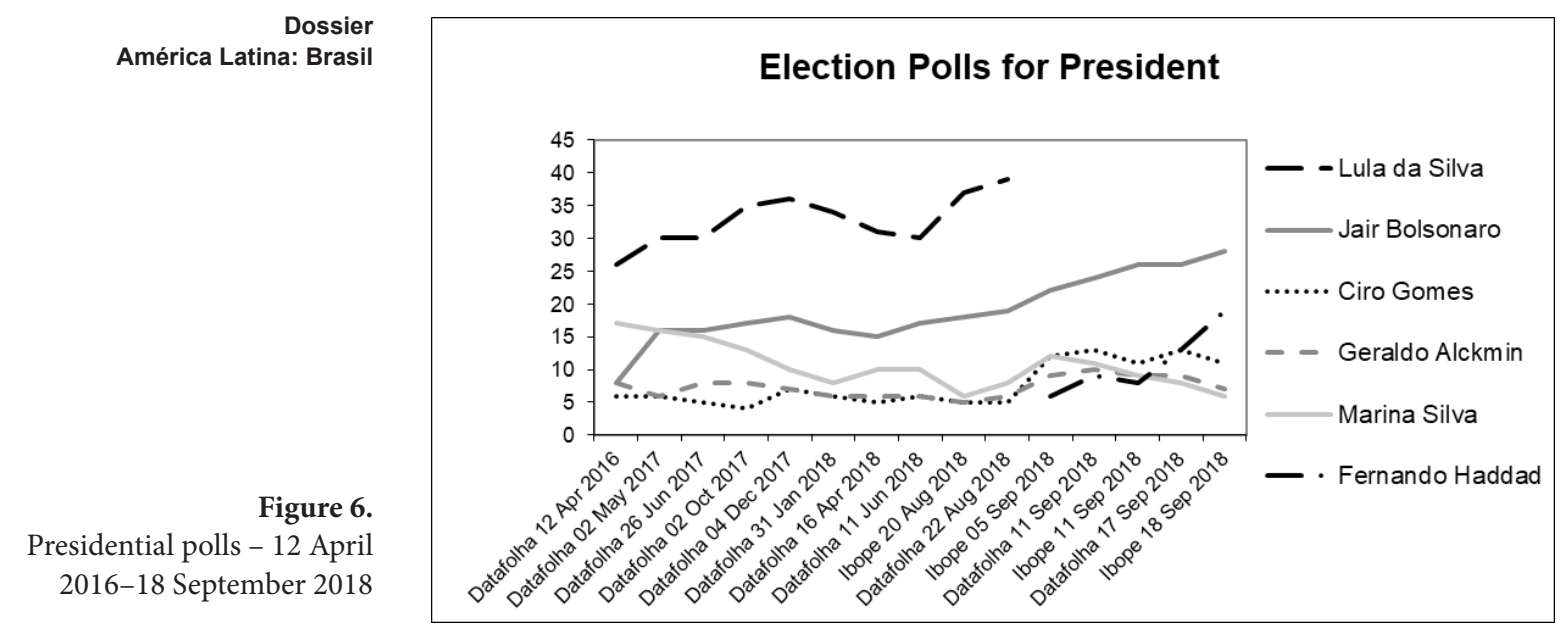

Source: Datafolha and Ibope presidential polls - 12 April 2016-18 September 2018.

do Haddad through the messaging application WhatsApp (Tardáguila et al., 2018). If these accusations are true, different kinds of electoral crimes have been committed: 1) electoral financing by firms is illegal in Brazil; 2) spreading fake news is obviously not permitted; 3) paying for flooding messages in WhatsApp during political campaigns is not allowed either.

\section{Conclusion}

As discussed in the present text, literature on democracy backsliding is often misleading. Executive aggrandizement or direct military intervention are often seen as the main (or unique) causes of democratic breakdown. Though, there are other monsters besides Leviathan killing democracy. Institutions responsible for checking may wreck democratic order in an "antagonist" way (contrary to an "agonic" behavior), such as the Judiciary. While searching for "populists", political science may neglect subtler coups and undemocratic schemes caused by the establishment.

Indeed, the very presidents accountable for the deepening of check instruments on Executive in Brazil were punished by them. Rousseff suffered a "coupeachment", and Lula became a political prisoner, unable to run in the election in which he led the polls. Besides the intended policy switch to the right, other side effects may be noticed in Brazilian politics since democracy ceased to be a commitment, returning to its undemocratic chain. First of all, the party system has been harmed, and the main parties that opposed PT shrank while backbenchers became more influential. Secondly, militarization grew both inside the government and on elections, what may lead to a rougher 
democratic breakdown in a near future if they behave as veto players or simply do not accept to leave. Thirdly, Brazilian society is not only divided, but violent values became more mainstream and openly sustained. As elections are no more the only game in town, and when they happen, there is no ex-post irreversibility, polity also became less predictable, with a broader range of variables to impact.

The Car Wash Operation ended in February 2021. In March, the Supreme Court cancelled Lula's conviction and also considered former judge Sergio Moro as suspect of bias. Lula became eligible again. Perhaps the road back to democracy began to be traveled. Alternatively, maybe the road is still too long, and militaries will be blocking the passage.

\section{Bibliographical references}

Almeida, F. (2018). Da Democratização da Justiça à Tutela Judicial da Democracia: Uma Interpretação do Protagonismo Judicial no Brasil Contemporâneo. In M. C. Marona, A. Del Río (Orgs.), Justiça no Brasil: Às Margens da Democracia. Belo Horizonte: Arraes.

Alvarez, M. et al. (1996). Classifying Political Regimes. Studies in Comparative International Development, vol. 31, no. 2, pp. 3-36. https://doi.org/10.1007/BF02719326

Arias, J. (2018, February 27). Por que tantos mimos de Temer aos militares? El País. Retrieved on 23 March 2021, from https://brasil.elpais.com/brasil/2018/02/27/ opinion/1519689207_346590.html

Avritzer, L. (2018). Inovando na Direção Errada: Supremo Tribunal Federal e Ministério Público no Brasil. In M. C. Marona, A. Del Río (Orgs.), Justiça no Brasil: Às Margens da Democracia. Belo Horizonte: Arraes.

Azevedo, R. (2015, August 31). O PT quebrou o país. Agora é oficial! Veja. Retrieved on 23 March 2021, from https://veja.abril.com.br/blog/reinaldo/o-pt-quebrou-o-pais-agorae-oficial/

Belluzzo, L. G. (2018, July 3). Descaminhos da Virtude. Carta Capital. Retrieved on 23 March 2021, from www.ihu.unisinos.br/188-noticias/noticias-2018/580511-descaminhosda-virtude

Brigido, C. \& Sassine, V. (2018, October 20). O general assessor de Toffoli, que faz pontes entre o STF e a caserna. Época. Retrieved on 24 March 2021, from https://epoca.globo. com/o-general-assessor-de-toffoli-que-faz-pontes-entre-stf-a-caserna-23168326

Bringel, B. (2013). Miopias, sentidos e tendências do levante brasileiro de 2013. Insight Inteligência, vol. 62, pp. 42-51.

Burke, E. (1790). Reflections on the Revolution in France. London: J. Dodsley.

Calixto, L. (2019, December 23). Dez fatos que ligam a família Bolsonaro a milicianos. Congresso em Foco. Retrieved on 24 March 2021, from https://congressoemfoco.uol.com. $\mathrm{br} /$ congresso-em-foco/dez-fatos-que-ligam-a-familia-bolsonaro-a-milicianos/

Carvalho, L. (2018). Valsa brasileira: Do Boom ao Caos Econômico. São Paulo: Todavia.

Chalhoub, J. \& Lima, P. L. (2018). Os juristas políticos e suas convicções: para uma anatomia
Necropsy on Brazilian Democracy

Guilherme Simões Reis 
Dossier América Latina: Brasil do componente jurídico do golpe de 2016 no Brasil. Revista de Ciências Sociais, vol. 49, no. 1, pp. 202-252.

Cheibub, J. A. (2006). Presidentialism, Parliamentarism, and the Survival of Democracy. Cambridge: Cambridge University Press.

Coelho, A. L. (2016). Um Novo Modelo de Destituição de Mandatários ou a Releitura de Velhas Práticas?: Reflexões sobre a instabilidade presidencial contemporânea na América Latina. Revista Brasileira de Estudos Políticos, vol. 113, pp. 11-50.

Coppedge, M. et al. (2017). V-Dem comparisons and contrasts with other measurement projects. Varieties of Democracy Institute: Working Paper, vol. 45. https://dx.doi.org/10.2139/ ssrn. 2951014

Dahl, R. A. (1971). Polyarchy: Participation and Opposition. New Haven: Yale University Press.

Del Río, A. \& Gomes, J. C. A. (2018, May 21). A quem serve a expansão da Justiça Militar? Le Monde Diplomatique Brasil. Retrieved on 24 March 2021, from https://diplomatique. org.br/a-quem-serve-a-expansao-da-justica-militar/

Del Río, A. \& Rodrigues, A. (2018, April 10). O que resta da democracia: Ampliação da justiça militar e a impunidade no Brasil. Le Monde Diplomatique Brasil. Retrieved on 24 March 2021, from https://diplomatique.org.br/o-que-resta-da-democracia-ampliacaoda-justica-militar-e-a-impunidade-no-brasil-2/

Diamond, L. \& Morlino, L. (Eds.) (2005). Assessing the Quality of Democracy. Baltimore: Johns Hopkins University Press.

Duarte, L. (2020). Os bastidores das reportagens que sacudiram o Brasil. In L. Duarte \& The Intercept Brasil, Vaza Jato: Os bastidores das reportagens que sacudiram o Brasil (pp. 8-113). Rio de Janeiro: Mórula.

Engelmann, F. (2018). O campo jurídico e a força do direito na política brasileira. In M. C. Marona \& A. Del Río (Orgs.), Justiça no Brasil: Âs Margens da Democracia. Belo Horizonte: Arraes.

Estrada, G. (2021, February 26). Operation Car Wash Was No Magic Bullet, The New York Times. Retrieved on 24 March 2021, from https://www.nytimes.com/2021/02/26/opinion/ international-world/car-wash-operation-brazil-bolsonaro.html

Feres Júnior, J. \& Sassara, L. (2018). Failed Honeymoon: Dilma Rousseff's Third Election Round. Latin American Perspectives, vol. 45, pp. 224-235. https://doi.org/10.1177\%2F0094582X18767429

Fernandes, S. (2016, May 25). The Right Marches on Brazil, Jacobin. Retrieved on 24 March 2021, from https://www.jacobinmag.com/2016/05/brazil-coup-impeachment-roussefftemer-pt-corruption

Figueiredo, A. C. \& Limongi, F. (1999). Executivo e Legislativo na Nova Ordem Constitucional. Rio de Janeiro: FGV.

Forrest, A. (2018, October 8). Jair Bolsonaro: the worst quotes from Brazil's far-right presidential frontrunner. Independent. Retrieved on 24 March 2021, from https://www. independent.co.uk/news/world/americas/jair-bolsonaro-who-is-quotes-brazil-presidentelection-run-off-latest-a8573901.html

Goulart, A. (2008, February 19). A mais polêmica edição do Jornal Nacional. Observatório da Imprensa. Retrieved on 24 March 2021, from http://observatoriodaimprensa.com.br/ entre-aspas/a-mais-polemica-edicao-do-jornal-nacional

Klein, C. (2016, March 31). O 'golpeachment'. Valor Econômico. Retrieved on 24 March 2021, from https://www.valor.com.br/politica/4505086/o-golpeachment 
Lessing, B. (2018, March 2). Brazil's federal intervention in Rio's drug wars has an authoritarian feel - and could backfire. The Washington Post. Retrieved on 24 March 2021, from https://www.washingtonpost.com/news/monkey-cage/wp/2018/03/02/brazilsfederal-intervention-in-rios-drug-wars-has-an-authoritarian-feel-and-could-backfire/

Levitsky, S. \& Ziblatt, D. (2018). How democracies die. New York: Crown.

Limongi, F. (2006). A Democracia no Brasil: Presidencialismo, coalizão partidária e processo decisório. Novos Estudos, vol. 76, pp. 17-41. http://dx.doi.org/10.1590/S010133002006000300002

Londoño, E. \& Casado, L. (2019, June 10). Leaked Messages Raise Fairness Questions in Brazil Corruption Inquiry. The New York Times. Retrieved on 24 March 2021, from https:// www.nytimes.com/2019/06/10/world/americas/brazil-car-wash-lava-jato.html

Löwy, M. (2016). Da tragédia à farsa: O golpe de 2016 no Brasil. In I. Jinkins, K. Doria \& M. Cleto (Orgs.), Por que Gritamos Golpe?: Para Entender o Impeachment e a Crise Política no Brasil. São Paulo: Boitempo.

Manso, B. P. (2020). A República das Milícias: Dos Esquadrões da Morte à Era Bolsonaro. São Paulo: Todavia.

Marona, M. C. \& Barbosa, L. V. Q. (2018). Protagonismo Judicial no Brasil: Do que estamos falando?. In M. C. Marona \& A. Del Río (Orgs.), Justiça no Brasil: Às Margens da Democracia. Belo Horizonte: Arraes.

Media Ownership Monitor, Official Website. Retrieved on 23 March 2021, from https:// www.mom-rsf.org/en/countries/brazil/

Monteiro, T. (2019, February 10). Planalto vê Igreja Católica como potencial opositora. O Estado de S. Paulo. Retrieved on 24 March 2021, from https://politica.estadao.com.br/ noticias/geral,planalto-ve-igreja-catolica-como-potencial-opositora,70002714758

Mouffe, C. (2000). The Democratic Paradox. London: Verso.

Mouffe, C. (2005). On the Political. London: Routledge.

National Coordination of the Homeless Workers Movement (2018, February 1). Reasons to Oppose the Lula Decision. Jacobin. Retrieved on 24 March 2021, from https://jacobinmag. com/2018/02/mtst-brazil-lula-conviction-biased-democracy

O'Donnell, G. (1998). Horizontal Accountability in New Democracies. Journal of Democracy, vol. 9, no. 3, pp. 112-26. https://doi.org/10.1353/jod.1998.0051

O’Donnell, G. (1999). Teoria democrática e política comparada. Dados, vol. 42, no. 4, pp. 655-90. http://dx.doi.org/10.1590/S0011-52581999000400001

Paiva, J. \& Do Sul, F. (2019, February 7). Estado Miliciano: A Consolidação da Ideologia e Ação. Escuta. Retrieved on 24 March 2021, from https://revistaescuta.wordpress. com/2019/02/07/estado-miliciano-a-consolidacao-da-ideologia-e-acao

Palermo, V. (2000). Como se governa o Brasil? O debate sobre instituições políticas e gestão de governo. Dados, vol. 43, no. 3, pp. 521-57. http://dx.doi.org/10.1590/S001152582000000300004

Pereira da Silva, F. (2018). O fim da onda rosa e o neogolpismo na América Latina. Revista Sul-Americana de Ciência Política, vol. 4, no. 2, pp. 165-78. https://doi.org/10.15210/ RSULACP.V4I2.14207.G9147

Perissinotto, R. (2016, October 7). Por que golpe. Paper presented at a meeting in the Institute of Social and Political Studies, Rio de Janeiro. Retrieved on 24 March 2021, from https://www.academia.edu/29221192/Por_que_golpe
Necropsy on Brazilian Democracy

Guilherme Simões Reis 
Dossier América Latina: Brasil
Phillips, D. (2018, July 12). 'Lesser evil': how Brazil's militias wield terror to seize power from gangs. The Guardian. Retrieved on 24 March 2021, from https://www.theguardian.com/ world/2018/jul/12/brazil-militia-paramilitary-wield-terror-seize-power-from-drug-gangs

Pogrebinschi, T. (2010). Participação como Representação: O impacto das conferências e conselhos nacionais na formulação e execução de políticas públicas. Brasília: Secretaria Geral da Presidência da República. Retrieved on 24 March 2021, from www.researchgate. net/publication/295699572_Relatorio_Final_da_Pesquisa_Participacao_como_ Representacao_o_impacto_das_conferencias_e_conselhos_nacionais_na_formulacao_e_ execucao_de_politicas_publicas

Przeworski, A. (2019). Crises of Democracy. Cambridge: Cambridge University Press.

Reis, G. S. (2017). O golpe de Estado de 2016 e a ditadura civil vigente no Brasil. In L. M. Monteiro \& L. Santana (Orgs.), Temerosas Transações: Ensaios sobre o Golpe Recente no Brasil. Santa Cruz do Sul: Essere nel Mondo.

Reis, G. S. (2016, June 14). O Pós-Golpe: O Que Temer?. Escuta. Retrieved on 24 March 2021, from https://revistaescuta.wordpress.com/2016/06/14/escuta-especial-conjunturao-pos-golpe-o-que-temer/

Reis, G. S. (2015). Como morre a democracia. Breviário de Filosofia Pública, no. 140, pp. 97-104.

Reis, G. S. \& Soares, G. M. (2017). O fascismo no Brasil: o ovo da serpente chocou. Desenvolvimento em Debate, vol. 5, pp. 50-71.

Rodrigues, F. (2014, June 16). Conheça a história da compra de votos a favor da emenda da reeleição. UOL. Retrieved on 24 March 2021, from https://fernandorodrigues.blogosfera. uol.com.br/2014/06/16/conheca-a-historia-da-compra-de-votos-a-favor-da-emenda-dareeleicao

Runciman, D. (2018). How Democracy Ends. London: Profile Books.

Santos, W. G. (2017). A democracia impedida: O Brasil no século XXI. Rio de Janeiro: FGV.

Schumpeter, J. (1942). Capitalism, Socialism and Democracy. New York and London: Harper \& Brothers.

Semer, M. (2016). Ruptura institucional e desconstrução do modelo democrático: O papel do Judiciário. In I. Jinkins, K. Doria \& M. Cleto (Orgs.), Por que Gritamos Golpe?: Para Entender o Impeachment e a Crise Política no Brasil. São Paulo: Boitempo.

Soares, G. A. D. (2001). A Democracia Interrompida. Rio de Janeiro: FGV.

Stokes, S. (2001). Mandates and Democracy: Neoliberalism by Surprise in Latin America. Cambridge: Cambridge University Press.

Tardáguila, C., Benevenuto, F. \& Ortellado, P. (2018, October 17). Fake News Is Poisoning Brazilian Politics: WhatsApp Can Stop It. The New York Times. Retrieved on 24 March 2021, from https://www.nytimes.com/2018/10/17/opinion/brazil-election-fake-news-whatsapp.html

Thatcher, M. \& Sweet, A. S. (2003). The Politics of Delegation. London and Portland: Frank Cass.

The Global State of Democracy Indices (2019). About. Stockholm: International IDEA. Retrieved on 24 March 2021, from https://www.idea.int/gsod-indices/about

Tinoco, G. \& Giambiagi, F. (2018, April). O Crescimento da Economia Brasileira 20182023. Perspectivas Depec 2018 - BNDES. Retrieved on 24 March 2021, from https://web. bndes.gov.br/bib/jspui/bitstream/1408/14760/1/Perspectivas\%202018-2023_P.pdf 
Veiga, L. F., Dutt-Ross, S. \& Martins, F. B. (2019). Os efeitos da economia e da Operação Lava-Jato na popularidade da Presidente Dilma Rousseff no período pré-impedimento. Revista de Sociologia e Política, vol. 27, no. 72, pp. 1-21. https://doi.org/10.1590/1678987319277202

Vianna, L. F. (2021, January 17). Na pandemia, Exército volta a matar brasileiros. Época. Retrieved on 24 March 2021, from https://epoca.globo.com/artigo-na-pandemia-exercitovolta-matar-brasileiros-24842973

Weisbrot, M. (2018, January 23). Brazil's Democracy Pushed into the Abyss. The New York Times. Retrieved on 24 March 2021, from https://www.nytimes.com/2018/01/23/opinion/ brazil-lula-democracy-corruption.html
Necropsy on Brazilian Democracy

Guilherme Simões Reis 